\title{
The Fight Against Terrorism
}

\section{Fatos Hasani}

Ph.D Candidate

\author{
Doi: 10.2478/ajis-2018-0021
}

\begin{abstract}
Understanding the phenomenon of terrorism, his perception and conceptual theories developed for this purpose have a special importance. Only after acquainted with a phenomenon, then we can face it. So after this process we can guarantee the highest possible protection of the rights and fundamental freedoms that can be put under a huge risk of such an operation of revealing the phenomenon. Providing consultancy to policy-making and executive power bodies, the active action in the fight against terrorism including the sciences product offer different fields, as a key instrument in this process is of special importance. Challenges they offer, the desire to serve a cause higher still, that of increasing the rights and fundamental freedoms on the highest pedestal, requires the scientists to do something more, which will inspire many other efforts in the future to assist in preventing and combating the terrorist threat. In this spirit, the technology offered policies for the EU and generally front against terrorism, a key instrument for achieving this goal.
\end{abstract}

Keywords: fundamental freedoms, operation, technology, preventing, combating

\section{Introduction}

The purpose of this chapter is to examine the changes in the perception of reality in the current developments in the international arena, those feelings of safety in the population of Western countries EU, USA, etc., Caused by the attacks of 11 September 2001 it in perceptions of safety and terrorism in Europe. To achieve this, I will start with an analysis of the system of international relations during the Cold War, after this, and coupled with the emergence of the concept of 'Islamic terrorism'. The concept of security, as it was reformulated through a conceptual redefinition due to the phenomenon of terrorism, and its high value political and economic elite of political and economic attribute, is the purpose of this chapter. Security is a public good, the absence (or reduction of sense of security) which quickly modifies the social contract, and entails serious difficulties in political, economic and technological. The concept of terrorism constitutes the other side of the security concept for the money is the main cause of violations in the second era of the Cold War. Both concepts have multiple interconnections between them. I will try to demonstrate that security policy efforts to eliminate the terrorist threat involving technological aspects. Technology implementation and application of the policy should include two distinct goals between them, which are to promote scientific base, technological and industrial, and defense against terrorist attacks. Objectives here, because undergo significant changes which raised the issue of modification of scientific research, freedom of research, conservation issue sensitive information from enemy hands, the issue of financing, implementation and exploitation of results, etc. For the writing of this article we are using secondary sources of popular subjects of international relations, political analysis, the economic relations and security studies. It is important to note at this point, any entity spasmodic approach mentioned above, about the impact of the terrorist threat in determining policies for the development of technologies. This article is an attempt to clarify conceptually or at least to show the boundaries of the concepts of security and terrorism related to technology. I believe that it is necessary that such an effort for two reasons: terrorist threats in terms of materialization of the terrorist attacks, may be restricted only by developing technological systems advanced or and application of technological systems existing in areas other than those for which initially they were created. Therefore, one approach to these concepts may prove to be a guide for determining the direction of technological progress. Moreover, due to the dual nature of the technology, and the technology it is used as a 
tool for carrying out terrorist attacks. It's so great penetration of technology in our daily lives (is so great that we are creating a reality of dependency on technology) that naturally makes us think that gaining control system technology by terrorists, can affect directly even in our most intimate moments.

\section{International Security Before and After 11 September 2001}

The study of international security has always been an area of intense dispute for trying to provide solutions to the eternal question of war and peace, liberation and subjugation, conquest and exclusion occupant, expansion and prevention. In most of the 20th century, the study had the objective relations between the two alliances, ideological, military and economic, Western alliance and the Warsaw Pact alliance. Since the Treaty of Westphalia in 1648 were set ground rules, that means that military activities would be strictly and only enterprise of the state apparatus. These relationships, although moved across a broad political spectrum, always based on some attitudes are acceptable such as that: entrepreneurs of combat operations are state bodies, activation of any formation other political, always serves the interests of the state concerned, the state is the sole authority and subject to the exercise of this right (military operations) with an army of its citizens. Unanimously approved rules for the exercise of military activity, but also respect for the right to life of civilians, in war as they are enshrined in international treaties. Military activity also has a clearly defined target (Invasion, submission, etc.) and should have an exit strategy from this situation (the war-situation). The drafters of these strategies should take into account that military activity is a short-term activity and that must stop with a peace treaty signed between the opposing parties, mediation, usually, to a third party. Twenty (20) years, of disputes connected with the study of the context of the notion went beyond the institutional framework of conceptual definition. Absolute conceptual redefinition was necessary after the terrorist attacks of 11 September 2001 in New York. Of course, Islamist terrorism as an activity against the interests of the Western world was not originally appeared in 2001, but attacks of 1998 in the US Embassy in Nairobi, and in Egypt, and the explosion in the warship USS Cole in 2000, have been warning signs an emerging threat. The attacks of 11 September 2001 marked and the first attack inside the US territory and constituted reason to change the dogma of security from the US in international relations and the regional classification of terrorism at the highest level in the hierarchy of threats, the calculating security interior, immigration policy, and in the analysis of this chapter, modified the configuration process of political technology. Moreover, because of the leading role of the US in the world community, the terrorist attack was an alarm and other countries. Technology within the political redefinition of scientific and technological priorities of the US government became a reference point for many national and international organizations, such as the EU. Terrorist message was clear: The era of stable and peaceful post-Cold War had already come to an end due to the international terrorist threat. The face of terrorism has changed and is connected to the public acts of mass violence; mass destruction and dramatic public events aimed at terrorizing citizens and symbolize a struggle between good and evil. According to Crashaw, new terrorists want nothing less than to change the world. Motivated by religious dictates, causing terror among observers and those in countries of the attacks, because they have no land link and accountable only a transcendental god or a mystical ideology. The terrorists already are willing to use lethal methods to destroy the polluted world as they perceive it, and to bring on the Apocalypse. This generation of terrorism requires mass death and achieve the purpose chooses to use suicide attacks or attempts to use weapons of mass destruction. Change of doctrine, the risks facing the global community, not just political relations changed and redefined the priorities of the majority of academic fields, discovering new liaison between them and expanded the existing disciplines in the light of developments. It should be noted that it is widely accepted opinion that competent academic fields have not succeeded in their mission, to predict or to inform policy makers about the possibility of an attack these dimensions. Economic science tries to analyze the phenomenon (terrorism) and to integrate the research and economic studies, studying economic information security, financing of terrorism, a matter of economic development.

\section{Security Concept}

Besides access to academic theories, or rather because of them (assuming that policy makers have to address the findings and proposals academic), addressing the definition conceptual importance (practical) and to the functioning of the international system, as it affects and changes the objectives of each member state of the Alliance. The importance of the ideological framework of political views and the unpredictability of history in national and international space together with the conceptual treatment, serves as a complement to political activity. EU especially when it ranked alongside elections optional US strategic friend who suffered because of the terrorist attacks set and the perception of the international environment. US-analyze all possible new threats through the prism of the war against terrorism list 
countries as members of the axis of evil that favor and produce terrorists, destabilizing the international order and threaten US hegemony. In fact, while it is coherent a significant number of issues of international security, as the economic potential financial and military rise of China, the possibility of nuclear conflict between India and Pakistan, nuclear research in North Korea and developments in Iran's nuclear ( already a priority of the US and EU treatment of this issue), expansion towards East European countries of NATO, and a series of new issues, such as global pandemics, continuing environmental degradation, mass migration. US choosing to interpret them through security point of view, as indeed they perceive itself, caused a polarization between traditional allies, particularly during the second term of G.W. Bush. Indeed, while this security strategy expressed by conservative instincts (preservation of American hegemony by preserving the status quo), to implement it was used almost illegal a number of measures towards this goal. The imposition of regime change, especially in Iraq and Afghanistan, why not in Syria will lead, supposedly, in the most stable state structure and thus a more stable international system. Hypothesis-assumption above, at the present time (2015), it is clearly rejected. There are relevant examples in countries such as Russia, which rushed to help in the fight against terrorism, only to legitimize its operations internal cleansing in the Caucasus, and Western Asia. Consistency with US interests provided an internal security policy without criticism of the oppression of human rights or interference from abroad in domestic affairs. At this point we must return to the concept of 'security" that can understand the consequences of his support in the international arena that have national leaders. The concept of security is an integral part of political theory and many philosophers and politicians have analyzed it. In fact many of these constituent elements that are attributed to this concept in the past, are completely valid and now. Different levels of security, international level, national and individual, the difference between security subjective (feeling of security) and objective, the idea of providing protection and security, the relationship between security and trust, as well as the wide range of interests, the such as social interest, which may be related to security, have made some aspects of the concept which is reflected fruitful. Ciceron security is subject to the supreme pleasure, is what allows the continuation of the happy life. For Smith, security is understood as the absence of violent attacks against his person or property of people of the same society. For Hobbes, security includes protection from foreign threats is essential for the development of society in every aspect. This perception of Hobbes was crucial for the field of international relations, and especially a very important school of thought, that of realists, who developed the idea of a strong state as a response to a situation of possible international anarchy. For Locke, the concept is necessary for the physical protection of society and creating conditions that will allow enjoyment of private property by individual's society. He also notes the possibility that the state jeopardize the citizens due to misuse of government power. The latter is the essence of the argument of those who believe that additional security measures in place to maximize the feeling of security to uncertainty. Indeed it can be said in cases involving the situation within the country and on the international stage. For Bentham, the purpose of government and legislation, is the pursuit of happiness for the greatest number of citizens, and understood as pleasure and security. This is a legal concept and focuses on the protection afforded by the law, despite the threat of internal or external. The same variety of interpretive approach concept continues in the 20th century. Areas addressed the concept, they are those of criminology and international relations. There is also a limited discussion of the concept of moral philosophy in literature about social justice and the rule of care, and the right to property. Criminology sector handles relations of security, democracy and control of traditional criminal offenses, emphasizing the importance of the internal security of a company. In the field of international relations definition of the concept varied depending on the individual schools of thought and different geopolitical situations (of the Cold War, the end of the Cold War, multi-polar systems, Islamic terrorism, etc.). However, the point of reference has always been his state and needed protection against armed conflicts or threats of any kind. It should be noted that these conceptual variations were more influenced by political programming than a real conceptualization of different points of view. In other words, the process of defining the concept depended on the respective political priorities instead of defining it. This highlights the need for defining and Buzan says, the concept is so poorly developed that manages to be unfit to perform his functions or when Matthews Tuchmann requires redefinition of the scope of the definition. Of course we are many definitions of the concept proposed by social scientists. For Freedman, security is defined as the level of trust that a country has in its ability to withstand an attack powered by another state. Morgenthau defined security (national) the condition of preserving the territorial integrity of infrastructure and appropriate institutional arrangements, while a subsequent analysis combined the concept of interconnection safety culture, arguing that the survival of a political entity with its own identity constitutes the minimum requirement, and essential element of its interests in the context of coexistence with other entities. It is worth mentioning that Laswell and Kaplan define security as expectations are high value (high value expectancy), where the expectation emphasizes nature subjective concept, and the character of the utmost importance, although it is a landmark objective, shows high expectations of entity to achieve its objectives. Woofers gave the definition of the concept, claiming that security, by 
accessing objective, measures the absence of threats to traditional values, and how you approach the subject [mat] lack of fear that such values will be the target of an attack next. So shown here, the two aspects of the concept (and the subjective and objective) and that the goal is a legitimate aim of coherent state policy. The distinction is important because policies to achieve maximum safety, designed for actual or potential threats. Moreover, for Woofers, security, wealth and power, it undergoes quantitative scales, because the concept is continuity and not an absolute concept, and that security is not reached once and will last forever. The tendency of achieving maximum security of a State may, for Woofers, conceal policies hostile offensive that a state designs against another, this, according to a subjective interpretation of the level of security in the status quo and grievances arising from this, too, according to realists, and the nature of security. Achieving the maximum level of security for a mean less security for $B$. schools of thought, choosing to define the concept differently, set in a real confrontation with the realists focus on threats of state power and strength and freedom from threats, neoliberal, although the focus of the state, stress cases cooperative international system. Constructive focus on institutions particularly those that enable inter-state relations. There are schools of thought that are identified by their geographical location. Copenhagen School examines the processes through which, on various issues related to security.

\section{The EU and the European Security Strategy}

The reaction of the Europeans in the attack of September 11, 2001 caused an extraordinary meeting of the Council of Europe on September 21 the same year the topic political dialogue deepened with countries and regions around the world where started already terrorism, and seeking state union, integrating them in a fair system of security, prosperity and development. The EU responded to the call for solidarity of the US, but made in a way that focuses on the causes of the birth of terrorism, based on a conceptual approach to security that emphasizes economic integration, the political and cultural relations of the peoples and conflict prevention, and to abandon the use of military route as the most favorable or only for the achievement of lasting peace and the protection of national security. As expected, the announcement later by the Americans, the war on terror and the invasion of Iraq, caused serious disagreements within the EU between those who supported not only a politically invasion, but materially (United Kingdom, Poland, Spain) and those who insisted in a preliminary ruling by the UN and negotiation exhaustion of policy instruments (Belgium, France, Germany). In another extraordinary meeting K.E Europeans reiterated their view of military intervention except as unique solution to the problem of Iraq, and argued with the background of the peace process between Israel and Palestine's. I will not focus on the possible impact of US developing Indo-European debate over the participation or not of the EU. On the other hand, the lack of adoption of a similar document to the US for the National Security Strategy, the typology of the dangers that threaten the EU and procedures, appropriate measures, and individual policy state that will be implemented it was a serious dispute reasons. The existence of such a document strategy, which will determine the context of the total, will specify areas of interest and will guide specific policy proposals (technical, industrial, military) is a necessary element of an organization supranational that has located on strategic interests and long-term political goals. In addition, as claimed by Betts, " without strategy, power is lost " [loose cannon] The absence of such a document was diagnosed, and the result was the European Strategy of Security (SES), which was developed by (then), KEPPAA High Representative, Javier Solana and endorsed by the European Council in December 2003. SES know-how global challenges and key threats for the EU and sets out strategic objectives such as the construction of a security in our area and the promotion of an international order based on effective multilateralism approach. SES's the feature of perceived within globalization, which imposes and accelerates adhesion aspects of external and internal security. While for some, the flow of trade and investment, technology development and the spread of democratic systems, resulted in a situation of stable prosperity and peace, for some, these rapid changes caused frustration and injustice. Furthermore, poverty, lack of food resources, the threat of epidemics such as SARS and HIV pose and these security issues, with economic bankruptcy closely associated with political controversy and violent riots. SES In any case, security is an essential condition for achieving development in all areas without exception, and treated in a broader perspective, which includes parameters of economic, humanitarian, etc., And generally no military parameters. SES, being the 'conscious' of the possibility of a military strike reduced high intensity against member states, recognizes five (5) threats:

1. terrorism,

2. the proliferation of weapons of mass destruction,

3. regional conflicts,

4. failure of the state, and

5. organized crime. 
To address these threats, several measures have been taken, as the institutionalization of the European arrest warrant, the fight against the financing of terrorism and mutual assistance agreement with the US law, which was passed after September 11. Moreover, the prevention of organized crime, reviving the failed states and good neighborly relations in the European geographical space, as it is already defined, have been identified as appropriate policies to strengthen security and prosperity in the EU. Particularly the goal of achieving good neighborly relations with geographic specific steps related to politico-military technological cooperation to create and activate joint mechanisms of prevention, to manage risk and to prevent conflicts. Recently, well-it functions international institutions like the UN are essential elements of an international order based on rules. However, for the effective functioning of these international organizations, will we need to be willing to hold position when their rules are broken. To achieve this goal, namely reacting appropriate, SES highlights the need for more active involvement on the broader and the most efficient EU cohesion of the global community. Active involvement with the term, conceived when preventive engagement is appropriate and necessary, and the development of a culture-strategic mindset that promotes (and) the intervention by force. The condition of achieving greater capacity, which includes the need for the transformation of the armed forces in the most flexible, efficient to enable them to cope with new threats. Also, references to the efficient use of financial resources expenses, related to the need to reduce of the financial agreements imposed to cover financial holes from member states of the EU. Provided greater durability, SES imposes combination of instruments and diplomatic skills, development and trade, and encourages environmental policies which should continue through the same directive. In this analysis, general and in this respect should be included and external activities of the Member States of the EU. Mutation of the national armed forces coherent military force, European as flexible, requires creating appropriate institutional infrastructure and operational in a single framework of national resources. In addition, a variety of instruments should unite to coordinate appropriately. In the words of SES, in a crisis, nothing can replace the unity of hegemony. In the overall context, SES is the first strategic document of the EU, and is a landmark not only for the CS \& PF (Common Foreign Policy and Defense [Common Security \& Foreign Policy]), but also for external relations of the EU 's. Major policy options contained in this document may regulate the international activity of the EU for many years. In any case, SES can not be ignored even by those who want the EU to act in absolute identification with NATO. However, the success of SES is not safe. To achieve this (success), the above options should conclude in concrete actions and implemented effectively to realize the original vision of the EU to play an important international role. This process is a document specification, absolutely political and not legal character can be a field of interpretations of the nature and content. It is understood that, depending on the interpretation, SES can be identified by its title, namely as a strategy long-term security for the global role and individual actions of the EU stemming from it, or constitute a simple text - meeting membered (the invasion of Iraq), not very important. In part, efforts in favor of the first version were the cause that prompted the EC to delegate back to the High Representative for CS \& PF (the Common Foreign and Defense [Common Security \& Foreign Policy]) Javier Solana, prerogative to design a review of SES amendment 2008. While the review included a series of risks and new threats, such as energy security, climate change, unresolved conflicts and relations with Russia, while implicitly indicates the need for coordination of specialized strategic policies and actions to implement them. In fact, this process recurring amending SES-it can be considered to have implications for institutional, economic, technological and administrative arising from the regulatory framework of the overall SES and should be applied if the Europeans want to be a force of good in this world. By identifying the threats category, and defining a set of measures solution, SES provided substantial assistance in drafting and developing a specific policy European defense industry by legitimizing the process. Moreover, the use of specific concepts in the document SES created a positive climate for the industry, because it was a harbinger of a framework to coordinate the activity European security sector, and joint activities for confronting effectively the threats of the new addressing its prey, such as terrorism, weapons of mass destruction, regional conflicts and organized crime.

\section{Conclusions}

In this article, I tried to present the policies and the direction taken by European policy-making institutions, not only in the field of technological policy after the terrorist attacks of 11 September 2001 in the US it. Sifted US case, for two reasons. The first has to do with the proposals of the US policy towards terrorist attack with the establishment of new institutional structures, redefining the priorities of national security, and financial decision corresponding increase in implementation of these projects, the product of political decision making. The second concerns the presentation of strong impulses that followed this redefinition-perception in the corresponding reaction of the EU. As is known, it has a relevant historical precedent, where the EU (then EC) being aware of the technological development deficit, hastened to cover it by funding 
new research projects. In the case of the EU, we tried to reflect on the respective institutional process. There is however a fundamental difference. In the case of the EU, there has been a confrontation institutional experience such a great challenge, and no historical precedent involvement of the European defense industry so far by setting national priorities and national security treatment at EU level of, attacks and terrorist threats that have already become part of a category of threats.

This process began by approving a document central European Security Strategy. That they were categorized types of threats to the EU, appropriate actions, and specific public policies such as policies on R \& D. SES- is the first and leading EU security classification process and its legitimacy as a matter of particular importance. As for setting research priorities, SES has made a point of reference for the majority of public documents, which determine the policy for the technology. These documents identify located in two axes. The first has to do with the treatment policy for scientific research, view contained therein and the integration of special security object Pillar 7th. The other has to do with the defense industrial policy, procurement-supply mechanisms and technical specifications. The axes can not be analyzed separately from each other but connected between them. Provision of technological products through improved security programs existing production lines of defense industries. Moreover, another goal of the EU, which is homogenization and the strengthening of competition between defense industries, achieved through the adoption of joint scientific research and technological prioritization and industrial. For the purpose of their acquisition, as instruments are recognized and research programs. In this chapter we analyzed the historical development of the procedure for setting policy on European security technology, using the findings of the relevant public documents, aiming especially the emergence of the cathodic process (top down), which began with the approval of SES, but also correspondent (bottom- up), through homogenization need defense industrial base. Europeans understood the need and importance of technology in the fight against the threats posed to the EU, and also the development and production of the latter by industry and scientific circles. And use of this instrument in the fight against terrorism was considered necessary, but the product, then the success remains to be seen yet. The use of dual-use technologies as a vital need for success and expectations was approved unanimously by the international community. Distribution of the terrorist threat in my opinion, ranking it in a special place on the list of threats, was, I believe, very spotted, as it facilitates decision-making with regard to the scale of policy priorities to resolve the problems that called regularly afford.

\section{References}

Allison, G., Morris, F., (1975), Armaments and Arms Control: Exploring the Determinants of Military Weapons, Daedalus, vol. 104 (3), fq. 99-129

Arce, D.G., Sandler, T., (2003), An Evolutionary Game Approach to Fundamentalism and Conflict, Journal of Institutional and Evolutionary Economics, vol. 159, fq.154

Armacost, M., (1969), The Politics of Weapons Innovation: The Thor - Jupiter Controversy, Columbia University Press

Arrow, K., (1962), Economic Welfare and the Allocation of Resources for Invention, te Nelson, R., (bot.), The Rate and Direction of Inventive Activity: Economic and Social Factors, Princeton University Press

Arrow, K., (1962), The Economic Implications of Learning by Doing, Review of Economic Studies, vol. 29, nr. 3, fq. 155-173

Arrow, K., Debreu, G., (1954), The Existence of an Equilibrium for a Competitive Economy, Econometrica, vol. XXII, fq. 265-90

Audretsch, D., Feldman, M., (1996), R\&D Spillovers and the Geography of Innovation and Production, American Economic Review, vol. 86 , nr. 3, fq. 630-640

Assembly of the Western European Union, (1994), The European Armaments Agency - Reply to the Thirty-Ninth Annual Report of the Council, teksti 1419, Assembly of the Western European Union

Atkinson, S.E., Sandler, T., Tschirart, J.T., (1987), Terrorism in a Bargaining Framework, Journal of Law and Economics, vol. 30, nr. 1, fq. 1-21

Avant, D., (2000), From Mercenary to Citizen Armies: Explaining Change in the Practice of War, International Organization, vol. 54, fq. 90

Bainbridge, W.S., (2003), The Future in Social Sciences, Futures, vol. 35, nr. 633-650

Baldwin, D.A., (1997), The Concept of Security, Review of International Studies, vol. 23.

Balzat, M., (2006), An Economic Analysis of Innovation. Extending the Concept of National Innovation Systems, Edward Elgar Publishing

Barth, K.H., (2003), The Politics of Seismology: Nuclear Testing, Arms Control and the Transformation of a Discipline, Social Studies of Science, vol. 33, nr. 5, fq. 743-781

Basalla, G., (1988), The Evolution of Technology, Cambridge University Press

Bascio, P., (2007), Defeating Islamic Terrorism: The Wahhabi Factor, Branden

Beck, U., (2009), World at Risk, Polity Press

Beck, U., Beck-Gernsheim, E., (2001), Individualization: Institutionalized Individualism and Its Social and Political Consequences, Sage 
Bentham, J., (1970), An Introduction to the Principles of Morals and Legislation, Athlone, London

Berman, E., (1990), 'The Economic Impact of Industry-funded University R\&D', Research Policy, fq. 349

Bertsch, G., (1988), (bot.), Controlling East West Trade and Technology Transfer, Duke University Press

Betts, R.K., (2000), Is Strategy an Illusion?, International Security, vol. 25, nr. 2, fq. 5-50

Bjiker, W., (1997), Of Bicycles, Bakelites, and Bulb, MIT Press

Bjiker, W., Law, J., (bot.), (1995), Shaping Technology / Building Society, MIT Press

Blain, M., (2009), The Sociology of Terrorism: Studies in Power, Subjection and Victimage Ritual, Universal Publishers

Blume, S., (1992), Insight and Industry - On the Dynamics of Technological Change in Medicine, MIT Press

Bondi, H., (1973), International Cooperation in Advanced Technology, The World Today, vol. 29, nr. 1, nr. 16-23

Bowker, G., Star, S., (1999), Sorting Things Out: Classification and its Consequences, MIT Press

Booth, K., (2007), Theory of World Security, Cambridge University Press

Bower, A., (1994), Essays in the Economics of Procurement, Rand, Santa Monica

Bozeman, B., Dietz, J.S., (2001), Research Policy Trends in the United States te Laredo, P., Mustar, P., (bot.), Research and Innovation Policies in the New Global Economy, Edward Elgar Publishing

British Eureka Chairmanship, (1986), Procedures for EUREKA Projects: Note by Chairman of the Ministerial Conference, DTI

Bronk, D., (1974), The National Science Foundation: Origins, Hopes and Aspirations, Science, vol. 188, fq. $409-414$

Browne, L., (1988), Defense Spending and High Technology Development: National and State Issues, New England Economic Review, vol. 1, nr. 1, fq. 3-22

Bruck, T., (2004), An Economic Analyses of Security Policies, Defence and Peace Economics, vol. 16, nr. 5, fq. 375-389

Bulletin of the European Communities, Supplement 14/73, (1973), Scientific and Technological Policy Programme, COM (73) 1250 Parts | \& ||

Bush, V., (1945), Science: the Endless Frontier. Report to the President on a Program for Postwar Scientific Research, GPO

Buzan, B., Herring E., (1998), The Arms Dynamic in World Politics, Lynne Rienner

Buzan, B., Waever, O., de Wilde, J., (1998), Security: A New Framework for Analysis, Lynne Rienner 